\title{
THE USE OF GROUNDED THEORY TO EVALUATE THE INTERACTIVE EFFECT OF FARMER ENTREPRENEUR AND ECONOMIC DEVELOPMENT OF GHANA
}

\author{
Ann Dodor ${ }^{1} \mathrm{CAI} \mathrm{LI}^{2}$ \\ Jiangsu University School of management No.301 Xuefu Road, Zhenjiang, 212013, P.R.China \\ Corresponding Author: Ann Dodor \\ anndodor@yahoo.com
}

\begin{abstract}
Widely seen is entrepreneurship being a key to competence which is necessary to build-up a developed economy globally. There is a consistent relationship between economic prosperity and entrepreneurial activities which have been confirmed by numerous studies from different theories perspectives at global level. The purpose of the research is to evaluate the effect of farmer entrepreneur and economic development using qualitative research approach where a score of successful entrepreneurs in all transcripts of interviews were analyzed by using the grounded theory. The results revealed that the farmer entrepreneur increased their competence through knowledge, skills and attitude. The "knowledge" results in the entrepreneur being a strategic planner, managing people and use technology. Skills acquired makes him a goal getter and negotiator. Finally, he have a positive attitude toward his work and customers and be proactive and tolerant. These attributes assist the entrepreneur to affect and develop the conomy of Ghana
\end{abstract}

Indexing terms/KeywordsGrounded theory, Entrepreneurship, economic development, farmer behavior.

\section{Subject Classification:Entrepreneurship}

Type (Method/Approach):Qualitative research with the use of grounded theory and Nvivo

Language : English

Date of Submission : 2018-03-13

Date of Acceptance : 2018-03-20

Date of Publication : 2018-04-30

ISSN : 2278-5612

Volume : 13 Issue : 1

Journal : INTENATIONAL JOURNAL OF MANAGEMENT AND INFORMATION TECHNOLOGY

Publisher : CIRWORLD

Website : https://cirworld.com

This work is licensed under a Creative Commons Attribution 4.0 International License. 


\section{Introduction}

According to the World Bank estimates, the economy of Ghana has achieved sustained growth, averaging about $6 \%$ annually since 2001 [4]. In relation to food security and poverty, Ghana was able to meet its Millennium Development Goal (MDG) of halving the proportion of hungry people in 2002 and was scheduled to achieve its MDG poverty target in 2015. As at the time of putting this study together, Ghana has still not achieved the target for food security and poverty [4]. Due to this remarkable achievement, in 2012 the World Bank re-classified Ghana as a lower middle income country [60; 54]. However, these achievements are not evenly spread across the country. For instance, the northern territory of the country has a worse statistics. A greater percentage of the farming and rural population still experience extreme forms of poverty and food insecurity [62]. This is a major concern because agriculture is the primary source of livelihood for about $50 \%$ of households in the country [36], accounting for about one third of the GDP [7]. Most farmers in Ghana are illiterate and lack basic entrepreneurial training. They lack the skills and technology to use and acquire innovative produce.

Entrepreneurs' becoming successful is important to the progress of society as entrepreneurship contributes to the creation of employment opportunities and a catalyst for economic growth [18]. Governmental bodies and policy makers acknowledge the fact that entrepreneurship play crucial role in economic and social development including job creation, unemployment reduction, social emancipation, and personal fulfillment [42].

However, in real life situation not many entrepreneurs are able to sustain their business venture. ${ }^{1}$

The right environment plays an important role in the promotion of entrepreneurship. Farmer entrepreneurs in Ghana are facing many constraints of numerous natures, which have dampened their spirit of entrepreneurship. Most rural farmers lack the requisite knowledge, skills and attitude for effective entrepreneurship. This study is undertaken to unmask the interactive effect of the farmer entrepreneur and the economic development of Ghana.

\section{Materials and Methods}

This part should contain sufficient detail that would enable all procedures to be repeated. It can be divided into subsections if several methods are described.

\section{Results and Discussion}

\section{Initial Results}

In this research, an initial result that was obtained from the field study has been analyzed with Nvivo software. After analyzing the transcribed interview texts, observations and document inspections conducted with the first eighteen participants, the researchers have been able to establish initial results of this study. For instance, 100 codes related to Knowledge emerged, which were grouped later into three categories (Strategic Planner (41), Managing people (19) and Use of technology (40). Additionally, 153 codes for Skills of farmer entrepreneur emerged which were categorized into five; namely, strategic skills (39), Goal getter (15), Negotiator (31), Risk taker (27) and strategic planner (41). Relating to Attitudes and behavior of farmer entrepreneurs, 77 codes emerged, which were grouped into four categories (proactive 17, tolerance 13, perseverance 17 and attitude and behavior 30).

In the next phase of this study, these initial results will be used to guide subsequent data collection and analysis that aimed to identify core categories and to develop the substantive theory of interactive effect of farmer entrepreneur on the economy of Ghana, which is the expected final outcome of the study. With the use of Nvivo software, the findings from the field was analyzed and below are the generated results.

\section{Discussion and Conclusions}

The relationship between entrepreneur competences, its development and entrepreneur performance in agro based industry represent an area which has fascinated researchers for decades. Recent research seems to acknowledge skills, knowledge and attitude of farmers in relation to their work and customers. To identify such linkages is important for agriculture practice and research. According to policy makers and researchers, enabling farmers into skillful and knowledgeable entrepreneurs will lead to more effective responses to development such as globalization and reforms in agricultural policies. In answer to our first Interview question, what knowledge do you have about the basics of entrepreneurship and its interactive effect on the economic development of Ghana? We can say that the farmer entrepreneur acquire knowledge through 
training which results in the entrepreneur being a strategic planner, managing people well and knowing how to use technology. Such knowledge will assist these farmers differentiate their farms from others in the same sector. The second Interview question which is related to the acquisition of skills was well answered and resulted in the farmer entrepreneur being more skillful enabling him to be a goal getter, negotiator and a risk taker. The last questions were answered with results of positive behavior and attitude of the farmer making him proactive, tolerant and persevere.

The linkage for the economic development means farmer entrepreneur has knowledge, skills and positive attitude to enhance their entrepreneur behavior. The theoretical framework used entrepreneur competence theory linking competencies and competence to 'KSA' theory and some well entrepreneur models. There are also some discussions on some methodological issues relating to adopting GT as the research method. A description of the initial phase of data collection, coding and analysis process with discussions of some initial findings is done. The researchers need to note some few issues on this study. As a requirement by constant comparative method, after each session of interview, data analysis has to be done immediately. Also to obtain more data when necessary, follow-up interview may be needed to conclude the study. Finally developing trust with participants is very important to produce quality data and ensure trustworthiness of research findings. At the concluding stage of this study, the researchers are expected to provide findings that will add to the existing literature of the interactive effect of farmer entrepreneur and the economy of Ghana.

\section{Main Text (Review only)}

\section{Background}

According to the World Bank estimates, the economy of Ghana has achieved sustained growth, averaging about $6 \%$ annually since 2001 [4]. In relation to food security and poverty, Ghana was able to meet its Millennium Development Goal (MDG) of halving the proportion of hungry people in 2002 and was scheduled to achieve its MDG poverty target in 2015. As at the time of putting this study together, Ghana has still not achieved the target for food security and poverty [4]. Due to this remarkable achievement, in 2012 the World Bank re-classified Ghana as a lower middle income country [60; 54]. However, these achievements are not evenly spread across the country. For instance, the northern territory of the country has a worse statistics. A greater percentage of the farming and rural population still experience extreme forms of poverty and food insecurity [62]. This is a major concern because agriculture is the primary source of livelihood for about $50 \%$ of households in the country [36], accounting for about one third of the GDP [7]. Most farmers in Ghana are illiterate and lack basic entrepreneurial training. They lack the skills and technology to use and acquire innovative produce.

Entrepreneurs' becoming successful is important to the progress of society as entrepreneurship contributes to the creation of employment opportunities and a catalyst for economic growth [18]. Governmental bodies and policy makers acknowledge the fact that entrepreneurship play crucial role in economic and social development including job creation, unemployment reduction, social emancipation, and personal fulfillment [42].

However, in real life situation not many entrepreneurs are able to sustain their business venture. ${ }^{2}$

The right environment plays an important role in the promotion of entrepreneurship. Farmer entrepreneurs in Ghana are facing many constraints of numerous natures, which have dampened their spirit of entrepreneurship. Most rural farmers lack the requisite knowledge, skills and attitude for effective entrepreneurship. This study is undertaken to unmask the interactive effect of the farmer entrepreneur and the economic development of Ghana.

\section{Literature Review.}

\subsection{Entrepreneurship and Entrepreneur}

\section{Basic Earlier Definitions}

Entrepreneurship study has a long history. One of the characteristics of earlier research results mostly focus on the entrepreneur not entrepreneurship. Entrepreneur is a word that originated from the French and means someone who 'undertakes' a venture or an enterprise. In the 18th century, the mercantilist Richard Cantillon(Cantillon, [8] defined entrepreneurs as risk-takers since their activities consisted of buying goods at a certain price and selling them in the future for an unknown price. The difference between the two prices, (that is the buying price and selling price) was therefore the entrepreneur's profit and the price of the risk 
taken in the transaction. Later, the Austrian economist Joseph Schumpeter viewed entrepreneurs as agents of change responsible for the 'creative destruction' that happens as a consequence of entrepreneurial activity, thus introducing the element of innovation [46]. Due to the fact that entrepreneurs are spread across the world, scholars can't base their way of thinking on one single definition. Nevertheless, the idea or concept of entrepreneur can find a holistic meaning according to Friend and Cook [13], which is to drastically cut down risk and bring success in any commercial activity through the knowledge of the organizational and managerial skills of an individual. [45] also described an entrepreneur as an individual who "shifts economic resources out of an area of lower and into an area of higher productivity and greater yield".

For a better insight into the concept of entrepreneur and entrepreneurship, Landstrom, iterated that the word "entrepreneur" referred to "violent warlike activities and was described as tough and willing to risk life and fortune" [24].

(Bjerke \& Hultman, [6] also defined an entrepreneur as "someone who specializes in taking responsibility for and making judgmental decisions that affect the location, form, and the use of goods, resources or institutions". They also added that entrepreneurs also need to manage the uncertainty in the business, demand and supply.

An entrepreneur is an independent agent who adopts a set of rules, consistent with a "search-and-satisfying" type of behavior, in order to reach goals such as the growth and profitability of his or her company.

Now, entrepreneurship has been widely identified as a potent factor in economic development by various economics and social scientists. The concept of entrepreneurship is attributed by various terms like 'innovation', 'organization building ability', 'gap-filling function', 'input completing', etc. The persons being attributed to, with these qualities are required to initiate and sustain the process of industrialization. Therefore, efforts are to be geared towards the search and development of such entrepreneurial skills and talents.

\subsection{Types of Entrepreneurs}

Various researchers have identified different categories of entrepreneurs based on different dimensions such as vision, intention, entrepreneur aspirations and others. Gunawan [15] in a study classified entrepreneurs into three different groups. They are economic, social and environmental entrepreneurs. Economic entrepreneur according to Gunawan, it is an entrepreneur who focuses only on profits and considers less on the sustainability of people and the environment. Richomme-Huet and De Freyman [38] describe them as regular entrepreneurs.

Social entrepreneurship on the other hand, is businesses for profit or nonprofit that strives to sustainably contribute to society and enact positive social change using entrepreneurial principles. The last types of entrepreneurs are the environmental entrepreneur also known as ecopreneurs. Kivirist and Ivanko [23] posited that although many entrepreneurs only focused on profit, an increasing number of ecopreneurs adopted different paradigm, focused on greening the bottom line and solving the problems in the society caused by their business. The difference between entrepreneurs and ecopreneurs lays on its business purpose where entrepreneurs are more profit-oriented while ecopreneurs are both profit- and eco-friendlyoriented business [15].

Looking at entrepreneurship differently, Navale [30] also identified four types or classifications of entrepreneurs. These are the innovator, imitator, fabian and drone [30]. According to Navale, the entrepreneur who is an innovator is one who gathers and synthesizes information and introduces new ideas and implements them. He is an industrial leader and strives for success. The entrepreneur who imitates is also identified as the adoptive entrepreneur. He waits for others to innovate before he adopts. The third type of entrepreneur Navale called the fabian entrepreneur. This person is very careful and timid. He will not imitate other innovators unless he is certain that the only way his business will not fail is to imitate [41].

The last type of entrepreneur is the drone who may be restricted to a few innovations. He will never adapt to changes in production even at the risk of losing heavily [3]. The above classification indicates two important issues in every economy. The first is that, well advanced economies which are making technical advancement have more innovative and adoptive entrepreneurs and few drones and fabians. Secondly, if the control and ownership of the organization is handled by fabians and drones technical advancement may be difficult to take place.

\subsection{Role of Entrepreneur in Economic Development}

Globally, every country tries to achieve maximum economic development. The economic developments of a country mostly depend on human resources. But obviously human resources alone cannot produce economic development; there is a need for dynamic and innovative entrepreneurs [52]. A country may be rich in natural 
resources but if it lacks entrepreneurship, it may not be able to use effectively the available resources and it may lag behind in economic development. Many developing countries experience such situations. Developing countries have realized the importance of entrepreneurs and earnest attempts are now being made to motivate and encourage entrepreneurs.

Entrepreneurs play a significant role in the economic growth and development of every country. They promote the prosperity of a nation by their innovation and dynamic leadership skills and knowledge. They create wealth and employment opportunities [47]. According to Teece, [52] entrepreneurs are prime movers of innovation, growth and as such, entrepreneurship is a dynamic force. Entrepreneurs assist in stabilizing societies, increases productivity, create employment, and grow the economy through innovation [28].

A study by Kilby, [22] indicates that developing countries have other functions that entrepreneurs are involved with such as: Management of scarce resources, dealing with public bureaucracy (licenses, taxes), acquiring and overseeing assembly of the factory, industrial designing and engineering, marketing of product and responding to competitions, industrial new product, perception of market opportunities (novel or imitative), financial and production management, management of customers and supplies relations, and management of scarce resources [22]. Every innovational activity raises the productive efficiency and effectiveness of an economy, resulting in greater output and income [32].

Niosi [32] envisaged that, economic growth occurs when more resources are available and in abundance in the economy. But he concluded that economic development is an entirely different phenomenon, as development occurs when output increases as a result of entrepreneurial activity. Schumpeter [46] therefore, defines development as "the carrying out of new combinations." Thus, innovational activities of entrepreneur raise the productive efficiency of an economy resulting in greater output and income. The entrepreneur as an innovator is the central figure in the process of development [12]. Thus, entrepreneurial activity stimulates progress and forms the mainspring of economic development. Entrepreneurs take action at the right time, and aim to achieve their goals by taking risks [61].

To attain economic gains and profit, an entrepreneur is one who identifies and seizes opportunities. Economic development of a country mostly depends primarily on its entrepreneurs. Entrepreneurs seizing opportunities establish businesses thereby bringing economic transformation. By their actions, inhabitants of counties have a better standard of living, get innovative products and satisfaction and the wide disparity in the levels of income is gradually reduced.

\subsection{Stages of Economic Development}

The relationship between entrepreneurship and country level of economic development has mainly been theorized following a framework by Porter [34;35]. The theoretical framework of economic development is divided into three stages: (1) the factor-driven stage, (2) the efficiency-driven stage, and (3) the innovationdriven stage. In the factor-driven stage, what is used by countries to compete is by utilizing low cost efficiencies in production of either low value-added products or commodities. Self-employment rate is high in small manufacturing and service firms, but generally entrepreneurial activity is low and no idea to create innovation or exporting [2].

In the efficiency-driven stage countries use economies of scale to compete. Basic services are the dominant industry sectors [5]. At this stage, self-employment and entrepreneurial activities will decrease as a result of increased returns on wage work and economies of scale. This far, entrepreneurship appears to be negatively related to economic development. The last stage is the innovation-driven stage the level of entrepreneurial activity is the highest, and also central to the competitiveness of the country. At this last point of economic development, the business service sector has expanded relative to manufacturing. Service firms are lesser on average than manufacturing firms, and provide more opportunities for entrepreneurship [2]. More opportunities for specialization are created due to information and communication technology which is wellspread [57]. Looking at the stages of economic development differently, Rostow [40] postulated a five layer stages of economic development: Traditional society, Transitional stage, Take off stage, Drive to maturity stage and High mass consumption stage [40].

In the diagram below, it is noted that, development requires substantial investment in capital. For the economies of LDCs to grow the right conditions would have to be created that may lead to rapid growth [50]. Small et. al [48] posited that there is actually more opportunities for entrepreneurship in developing countries [48], and similarly, Jamali [21] indicated that the demand for entrepreneurship is particularly high during economic development [21]. He added that entrepreneurship does not seem to flourish in less developed countries due to entrepreneurship being perversely allocated into rent-seeking activities. That is, with another incentive structure, the allocation could be shifted into productive entrepreneurship even in lower stages of economic development [29]. 
Figure 1: Stages of economic development. Author's construct.

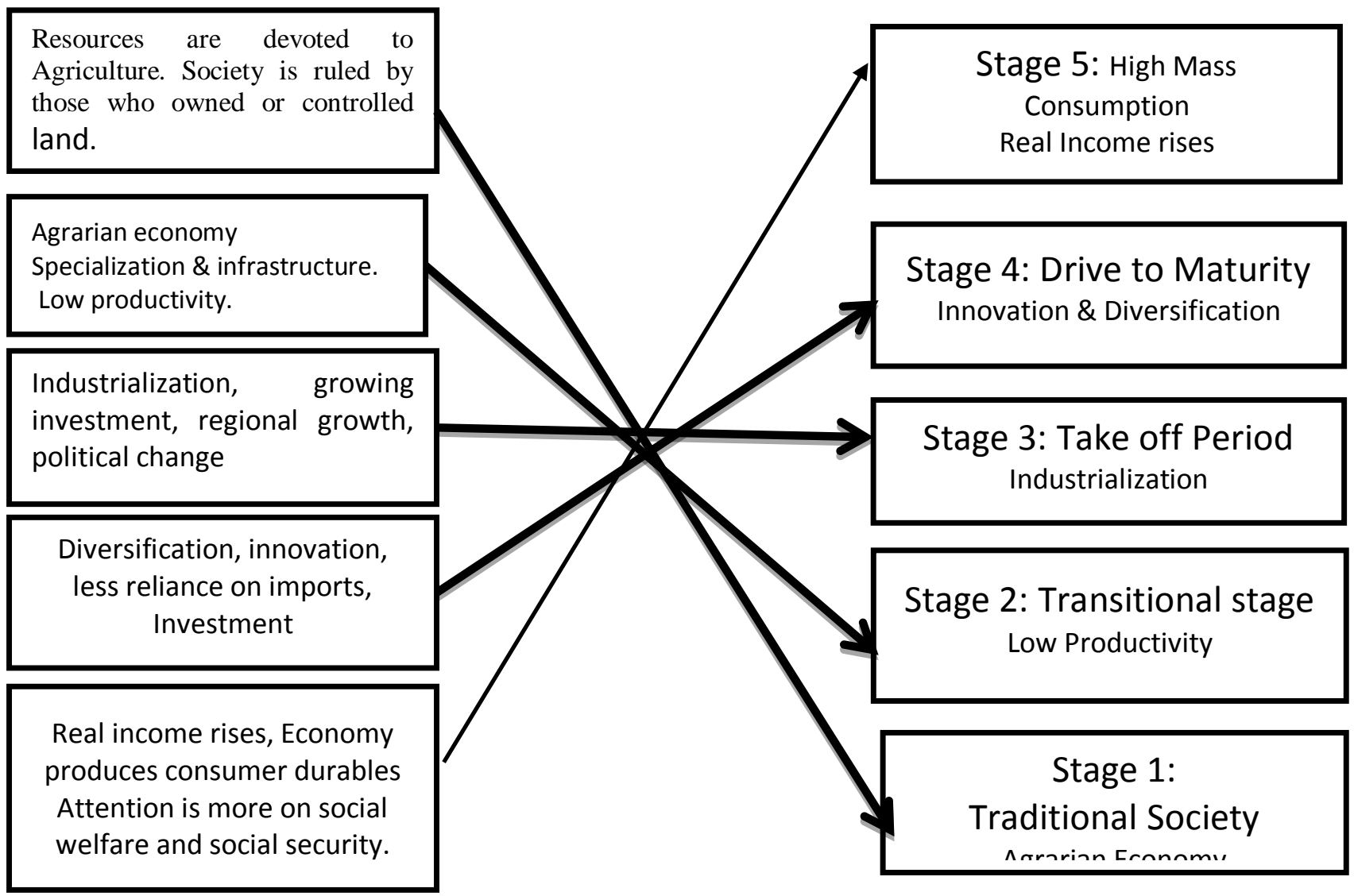

\subsubsection{Entrepreneurial Competencies}

As defined by Sarwoko et.al [43] entrepreneurial competency is the individual characteristic including attitude and behavior, which allow the entrepreneur to achieve business success [43]. Generally, competencies are the characteristics of people that differentiate performance in a specific job or role. Furthermore, in a book published by National Research Council [11], it is noted that, competencies which are resources for development encompass clusters of skills, knowledge, abilities, Ideas and behaviors required for people to succeed. Below are lists of authors who have researched on competencies [11].

$\mathrm{Li}$ [26] iterated that entrepreneurial competencies are a set of higher-level characteristics involving personality traits, skills and knowledge [26]. Rihava, Buhalis et al [39] have noted that competence refers to tangible and reckonable outcomes such as actions and performances that can be eventually assessed against standard measures [39]. Toporek, et. al [53] indicated that, competencies can be learned and can change allowing intervention in terms of the selection, training and development of entrepreneurship [53]. Man et. al [27] concluded that entrepreneurial competencies are a set of higher-level characteristics involving personality traits, knowledge and skills [27]. Rihova et al [39] analyzed nine areas of entrepreneurial competencies which they considered as an important aspect to the success of entrepreneurship in Niger [39]. These are: time management, communication, human resources management, marketing management, business ethics, social responsibility, leadership, decision making and financial management. Ahmad, Ramayah and Kummerow [19] used the measurement of entrepreneurial competencies covering: strategic, conceptual, opportunity, relationship, learning, personal, and ethics [19]. Lee and Hsieh [25] opinion that for entrepreneurship to be sustained and successful, the entrepreneur should exhibit attributes such as, values, beliefs, knowledge, skills, abilities, positive attitude, personality, wisdom, expertise (social, technical, managerial), mindset and behavioral tendencies [25].

Resources such as knowledge, skills, attitudes, behavior and ideas can assist a person's capabilities [39]. A person with a capability has a potential to acquire a specific ability or skill that will assist him in his duties. The skill acquired or ability adds to a person's knowledge bank or skill set. Capabilities also increase the functions of a person which can lead to more efficiency and productivity [16]. Some capabilities can make an individual a good strategic planner, manage people well, ability to use technology, be a goal getter, be proactive, tolerant and persevere. New skills and abilities make a person more capable to complete a certain job or a 
more suitable candidate for a job position. Competence on the other hand, can also result in an increased quality of work or performance [56]. In return, the work and performance will produce more satisfying and favorable results. Competence starts from a person's capabilities. In a sense, competence is the proven abilities and improved capabilities. Competence can include a combination of knowledge, creativity, innovativeness, tolerance and self-confidence which can lead to core competence.

Figure 2: Entrepreneur competences

\begin{tabular}{|l|l|l} 
RESOURCES \\
Knowledge \\
Skills \\
Attitudes \\
Behavior \\
Ideas
\end{tabular}$\longrightarrow \begin{aligned} & \text { CAPABILITIES } \\
& \text { Strategic Planner } \\
& \text { Managing people } \\
& \text { Use of technology } \\
& \text { Goal getter } \\
& \text { Negotiator } \\
& \text { Risk taker } \\
& \text { Proactive } \\
& \text { Tolerance } \\
& \text { Persevere }\end{aligned}$

\subsubsection{Entrepreneurial Competencies Models}

As defined by Sarwoku et al.[43] a competency model is a set of competencies often organized into clusters of knowledge, skills, abilities, Ideas, and behavior for a specific purpose [43]. Man, Lau and Chan [27], have concluded that, for employees to be effective and successful, they need a detailed description of a competency model to adapt, as this is a success factor which can lead to high performance [27]. The justification of the use of the competency model is to provide a road map for the range of behaviors that produce good performance [25].

One major entrepreneurial competency model that can easily be accessed for study is the Generic Entrepreneur Competency Model developed by Mansfield, McClelland, Spencer and Santiago [49] for the purpose of identifying potential successful entrepreneurs; The Generic Entrepreneur Competency Model is completely described in the book Competence at Work: Models for Superior Performance. The Model comprises seven clusters (achievement, thinking and problem solving, personal maturity, influence, directing and controlling, orientation to others, and additional competencies), and each cluster have a number of separate competencies; in total there are 22 competencies in this model [49].

Another model for entrepreneur competency developed by the National Research Council of Canada (NRC) is for the purpose of supporting employees in making a successful transition to entrepreneurship in a technology or science-based business venture [11]. The NRC Entrepreneurship Model is fully displayed on the website of the NRC. The model is divided into three clusters namely: achievement/results orientation, interpersonal and team-building, and business focus. Every cluster of the model involves some varied competencies according to different levels.

\section{Methodology}

It has been stated by Patton [33] that the nature of problems in farmer entrepreneurs' effect and an economy and subjective understanding of their reality require qualitative methods (Patton, 2005). Based on Walsham [59]Hughes and Jones (2003)the qualitative direction is fully compatible with the interpretive information systems (IS) research [59; 20]. Therefore, what is needed is an accent on evaluation that is concerned with the process of devising questions, and interpreting the answers that give results in a systematic way

The justification for using Grounded Theory in evaluating farmer entrepreneurs' effect and an economy is based on the principle that GT provides a set of procedures for coding and analyzing data which suits the interpretive approach since it would keep the analysis close to the data and provide inductive discoveries about the phenomena under study [1]. In brief, the methodology of Grounded Theory is iterative, requiring a steady movement between concept and data, as well as comparative, requiring a constant comparison across different types of evidence to control the conceptual level and the scope of the emergingtheory.

\subsection{Grounded Theory}

Grounded theory (GT) is the qualitative research methodology that will be used in this study. Any research that aims to build a theory can use GT as it is an interpretative enquiry method [9]. GT method has been identified as a superior research method where theories are generated inductively which are 'grounded' in data and not derived deductively from the existing theory. Other research methods can be differentiated from 
GT establishing six criteria which can be based on literature. (1) the aim of qualitative data analysis is to generate new theories or concepts; (2) the theories that are generated are empirically "grounded" in data about reality; (3) the use of pragmatic data analysis approach; (4) the outcomes is usually based on inequality individuals and unique situations; (5) it is based on an open minded study approach; and (6) to allow flexibility in research designs to take care of unpredicted participants such as sampling size. One basic fact about GT is that, data gathering and analyses phases are done at the same time and systematically using constant comparison method [14]. Results that are expected from the study of GT are an emerging theory, which is derived from data, not from inferences of existing theories. Finally, one thing that makes GT method unique is that in order to generate a theory, a flexible and creative research process should be used [51] and at the same time revising and writing of memo during the analysis.

The process of the grounded theory by Chamez, [9] starts with a research question. This is followed by data collection and initial coding. After the initial coding, focused coding will lead to conceptual categories that will result in theoretical sampling. The final step is to integrate categories to core concepts which will result in a theory [9].

\subsection{Justifications for adopting GT}

The study adopted GT method to assess the Interactive effect of the farmer entrepreneur and the economy of Ghana. These factors will be identified and described through generation of codes and categories during the analysis stage [32]. Enumerated below are some few justifications to support our GT study [58]. First and foremost, this study is categorized as an exploratory research study, which is suitable for a qualitative research approach employing GT method. Secondly, it is greatly useful for this type of enquiry that needs to observe and understand what the farmer entrepreneur can do to affect the economy of Ghana. Thirdly, GT is also a suitable method to identify the knowledge, skills and attitudes of the farmer entrepreneur [37]. Fourthly, the qualitative research study methodology using GT method is suitable to conduct in-depth study using richer set of data from research participants, which could not be provided by a quantitative study method. Fifthly, as an exploratory study that focuses on a specific group of participants, it is possible to conduct meaningful study to determine whether farmer entrepreneurs have enough knowledge and skills to affect the economy of Ghana [17]. The most important thing about this study is to develop a substantive theory that is 'grounded' in the data as contrasts to quantitative method, which aims to test the existing theory [9]. However, with the dynamic nature of GT method, new researchers are advised to focus on generating substantive theory rather than formal theories which are developed from many substantive theories [51]. GT approach is therefore, chosen in this study to construct a substantive theory on the effect of farmer entrepreneur and the economy of Ghana [44]. Finally, by using GT method, the researchers hope to provide another perspective on the interactive effect of the farmer entrepreneur and the economy of Ghana studies that will contribute a valuable input to the body of knowledge as most literature so far employed quantitative research approach i.e. survey method. Thus, GT, as a qualitative method is highly needed for the research in the effect of the farmer entrepreneur and the economy of Ghana [44].

Glaser and Strauss $(1967,2009)$ who came up with the original version of GT are considered the Classical GT approach. This approach stresses on objectivity; external reality and acting as an unbiased observer. Other researcher like Strauss and Corbin, proposed a GT approach which is classified as the emerging GT. [9]This approach according to the authors assumes that researchers should have unbiased position, emphasizing on applying prescribed procedures, yet still allowing the participants to have their own voices. Constructivism is another GT approach proposed by Charmaz [9], this approach is based on constructivist perspective, emphasizing on being pragmatist and contemporary constructivist. This study adopted the constructivism GT approach. This approach is considered relevant to the study as having research back ground as new researchers' for grounded theory [51]. Hence, based on this approach, we employ initial coding; focus coding and theoretical coding during the analysis. To add to the work, the study also adopted 'paradigm model' approach for seeking a core category.

\section{Field studies and Findings}

Research participants were selected during field study to gather data, using initial and purposive sampling (that is the use of sampling which is picking relevant participants that fulfill criteria that will lead to relevant data). They are selected from farmers who are into small and medium scale farming. This purposive sampling plan was done immediately after a meeting with the farmers' Association of Ghana to gather a sample of farmers who are into the production of cocoa (a cash crop). Data was gathered using semi-structured interview and followed by observations at the various farms of participants to determine whether farmers have the requisite knowledge, skills and attitude and also to assess the effect of their entrepreneurship and the economy of Ghana. Before interview, each participant was taken through a letter of consent because most farmers are illiterates and cannot read and write. During interview session, participants were interviewed in- 
depth using an interview guide and recorded instruments. Interview sessions (around 30 minutes each) were aimed to let participants express (1) their knowledge in the basics of entrepreneurship, skills of the farmer entrepreneur, and the attitudes of the farmer entrepreneur. In addition, notes were taken during observations describing how participants act/react, take actions or engage in their farming activities.

As stipulated by Chamaz [9] data analysis should be done at the same time as collection of data. Chamaz suggested that the use of constant-comparative method procedure should be used during qualitative research. (i.e. immediately after each interview and observation it should be completed before the next interview is performed). However, since most of the participant are illiterates and are working during the interviews period, the first three interviews were conducted on the same day and subsequently analyzed in the following days. At the initial phase of the study, the three interview questions were tried to answer: (1) what knowledge do you have in the basics of entrepreneurship? (2) How will you use strategic skills to set priorities and focus on goals? (3) How will you use your attitude and behavior to be action oriented, an initiator and proactive? Below is one of the interviews with a participant, indicating how the data was generated.

\subsection{Face to face Interview with a participant}

\section{Interview with Mr. Arthur on March $26^{\text {th }} 2015$ at his farm In Western Region of Ghana.}

Interviewer - Emmanuel

Tell me about your personal and family history in farming. How long have you or your family been working as farmers?

Interviewee - Mr. Arthur

Most of my family members are into farming. Some are into horticulture and others into agro based and fish farming.

Emmanuel

Who/what motivated you to go into farming?

Mr. Arthur

I guess my extended family members. Right from childhood I was ushered into farming by my parents and it has continued since then.

Emmanuel

How many years of farmer entrepreneur training do you have in this field

Mr. Arthur

As I said earlier, I have several years' experience because my parents started giving me basic training at a very tender age. I am currently thirty years of age. I started active farming when I was 18 years.

Emmanuel

What knowledge do you have about the basics of entrepreneurship, idea generation opportunities, finance, technology, and marketing?

Mr. Arthur

Two times in a every year the government organizes training for all farmers in this community. We are taught new farming methods, when and how to plant our produce and how to water the plant when the rains are not coming. We also have farmers association in this community. We meet occasionally to deliberate on issues and generate new ideas. The association sometimes invites learned people to train us on how to plan strategically and manage the people we work with. We use our farms as collateral for loans from the banks to expand our business. The government and other NGOs come to train us on the use of new tools and new technology.

Emmanuel

What skills do you have or need to secure resources for your business?

Mr. Arthur

I need financial skills to help me get enough money to expand my business. I also need emotional skills to keep me going and motivate myself for the farming business.

Emmanuel 
What farming skills do you have or need?

Mr. Arthur

I organize my time very well. I spend more than 12 hours a day every day on the farm except Sundays. I ensure that farm produce are properly transported, stored and delivered from the farm, to wholesalers and to consumers.

I need knowledge and skill to use current technology, particularly in terms of agriculture practices, is incredibly important. This includes a focus on things such as irrigation, pesticide-use, and improving methods and techniques of cultivation, harvest, storage and transport

Emmanuel

How will you use your skills during the planting and harvesting period?

Mr. Arthur

I have a skill of when to plant seeds, when to water the plants and how to mix fertilizer and apply to the plants. I also have skills in harvesting the produce at the right time and sending to the market.

Emmanuel

How will you use your skills to sell your end produce?

Mr. Arthur

I have excellent negotiation skills. When the middle men or distributors visit my farm for the produce I know how to negotiate for a better price.

Emmanuel

How will you use strategic skills to set priorities and focus on goals?

Mr. Arthur

Farming is full of risk, as you cannot predict the weather. I am a risk taker because I have invested a lot of money into the farm and I have to be a goal getter. I plan my itinerary every day for different things to do on my farm for better results.

Emmanuel

How will you use your Attitude and behavior to overcome adverse circumstance?

Mr. Arthur

I try to calm down always as farming can be full of surprises. I am very tolerant. I try to adapt to uncertainty and ambiguity. You anticipate for a bumper harvest during a particular year but can turn otherwise. I try to always have an alternative plan.

Emmanuel

What behavioral traits will you exhibit for people to see that you believe in yourself?

Mr. Arthur

I really believe in myself to achieve results at the end of every farming season. As action always speak louder than words.

Emmanuel

How will you be action-oriented, initiator and proactive?

Mr. Arthur

I am very proactive as I inherited this trait from my parents. Where there need to be changes I do it immediately. I create novel thought/ actions, unpredictable, radical change and innovative, visionary actions. 
Nvivo software generated Interviews with participants

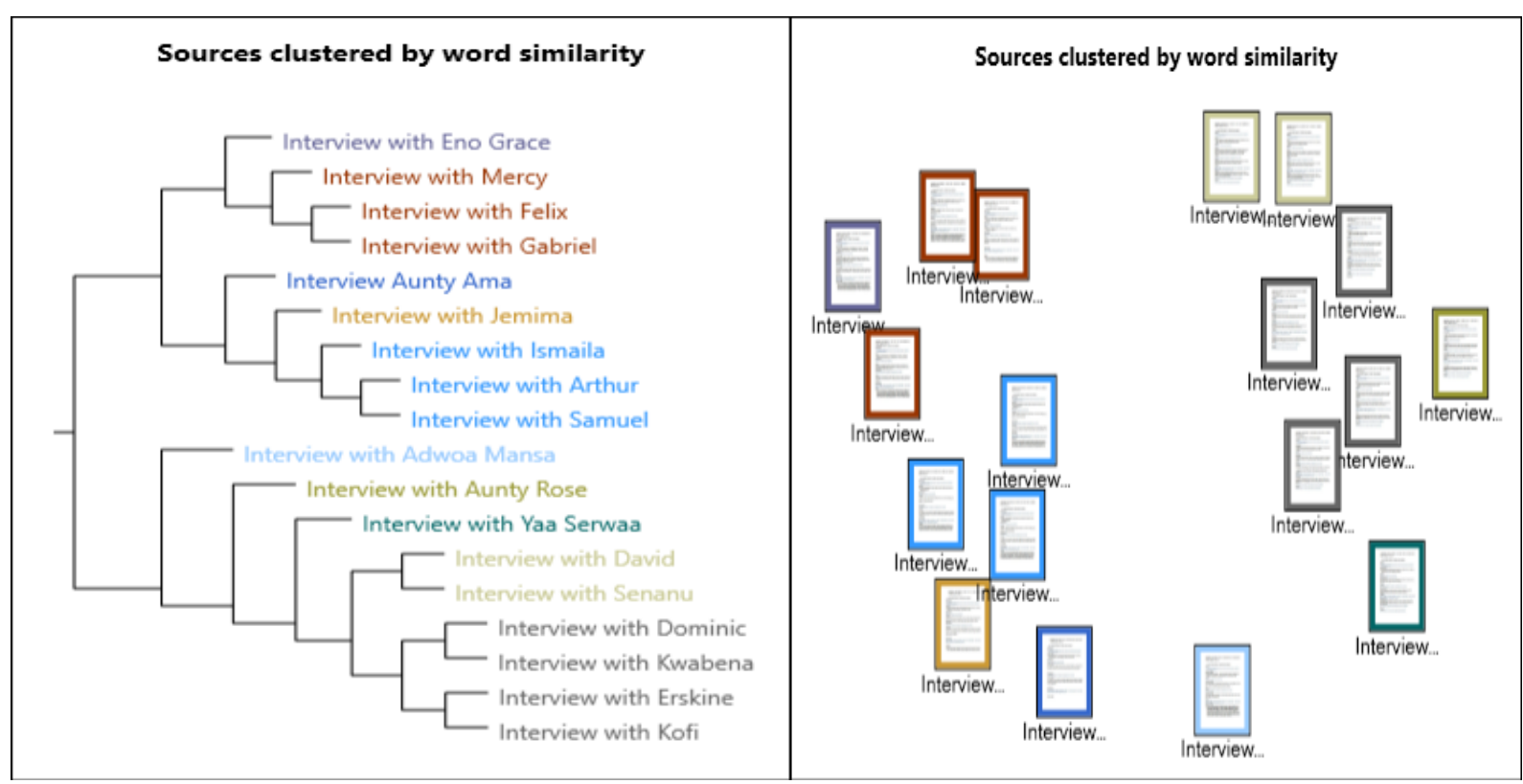

\subsection{Coding and Analysis of field studies}

Nvivo software facilitated the coding process. This was done converting contents from the field into codes after information are transcribed in textual content. Coding is a process of naming/labeling/categorizes on transcribed interview texts and recorded description of field notes made by the researchers during field studies. Analysis also followed the constant comparative method i.e. comparing incident to incident in data to generate codes and categories. In this research study, three steps coding stages followed by ; 1 ) initial coding (e.g. identifying, naming or labeling, categorizing interview texts); followed by (2) focused coding (e.g. sorting, synthesizing, integrating and diagramming) and (3) theoretical coding (e.g. identifying relationships between categories, conceptualizing codes, integrating the theoretical memos in developing the final theory [9]. In the final analysis, reduction process is employed to integrate categories and their properties to generate meaningful concepts. The researchers identified that during analysis, theoretical sensitivity aspects must be observed so as to avoid forcing data to generate theory. Rather, data itself must emerge that finally suggest the theory.

The most fundamental process in grounded theory is coding. This can be carried out line-by-line, sentenceby-sentence, paragraph-by-paragraph, page-by-page, section-by-section, and so on. If the unit of analysis is smaller, (e.g. one line of text) the descriptive categories that emerge initially will be numerous [10].

An initial coding task was done using open coding, in nvivo coding and code-by-list. For instance, to answer the first Interview question, the researchers developed coding list thus creating codes such as "strategic planner", "managing people" and "use of technology". The second Interview question being answered took a similar format as the first. Codes such as "Strategic skills", "Goal getter", "Negotiator" and "Risk taker" were listed. Accordingly, to answer the third Interview question on how participants will use their attitude and behavior to be action oriented, initiator and proactive, the researchers listed codes such as Proactive, Tolerance and Perseverance.

\subsection{Initial Results}

In this research, an initial result that was obtained from the field study has been analyzed with Nvivo software. After analyzing the transcribed interview texts, observations and document inspections conducted with the first eighteen participants, the researchers have been able to establish initial results of this study. For instance, 100 codes related to Knowledge emerged, which were grouped later into three categories (Strategic Planner (41), Managing people (19) and Use of technology (40). Additionally, 153 codes for Skills of farmer entrepreneur emerged which were categorized into five; namely, strategic skills (39), Goal getter (15), Negotiator (31), Risk taker (27) and strategic planner (41). Relating to Attitudes and behavior of farmer entrepreneurs, 77 codes emerged, which were grouped into four categories (proactive 17, tolerance 13, perseverance 17 and attitude and behavior 30 ).

In the next phase of this study, these initial results will be used to guide subsequent data collection and analysis that aimed to identify core categories and to develop the substantive theory of interactive effect of 
farmer entrepreneur on the economy of Ghana, which is the expected final outcome of the study. With the use of Nvivo software, the findings from the field was analyzed and below are the generated results.

Grounded Theory Resulting From Nvivo

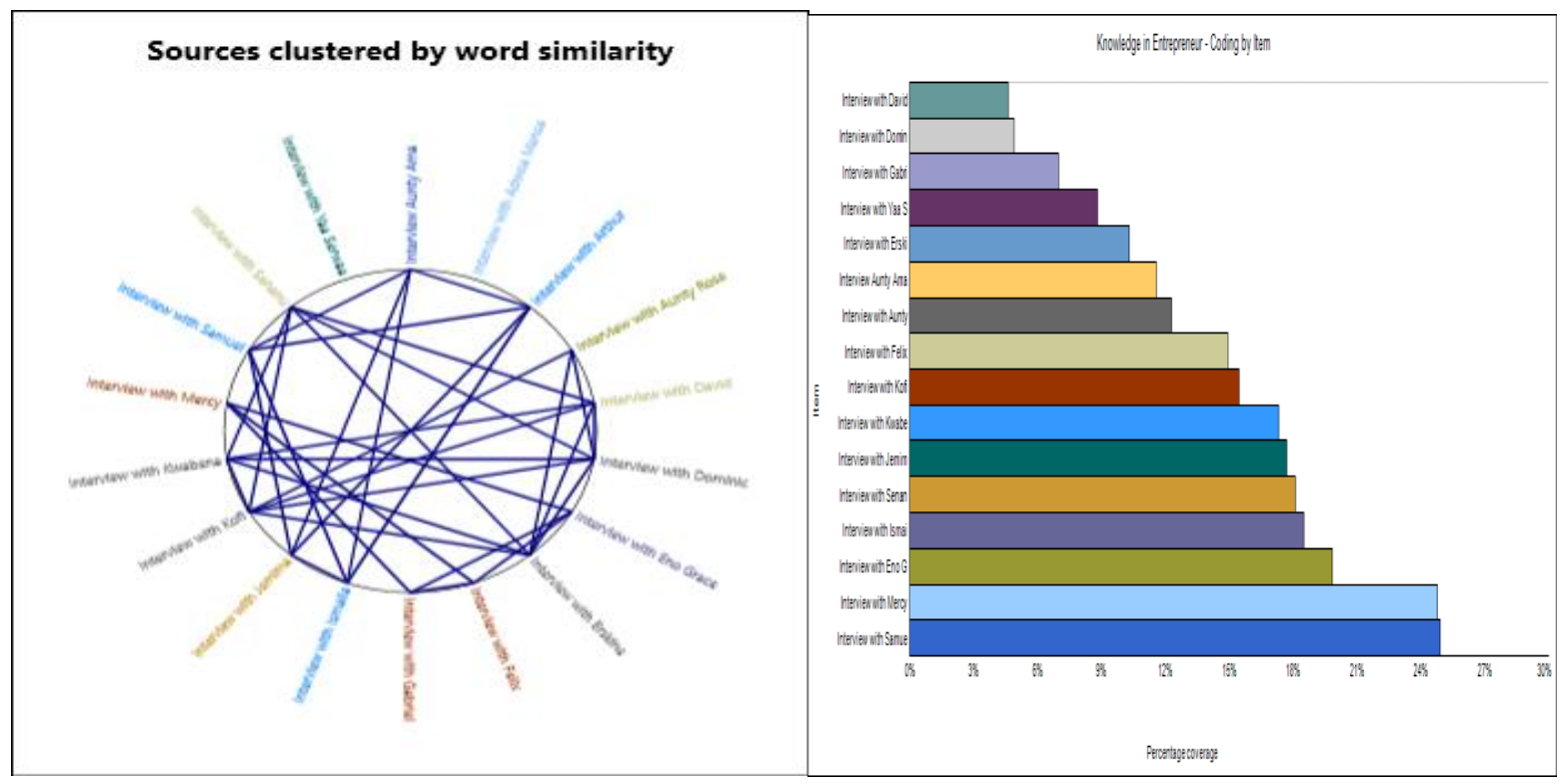

\section{Discussion and Conclusions}

The relationship between entrepreneur competences, its development and entrepreneur performance in agro based industry represent an area which has fascinated researchers for decades. Recent research seems to acknowledge skills, knowledge and attitude of farmers in relation to their work and customers. To identify such linkages is important for agriculture practice and research. According to policy makers and researchers, enabling farmers into skillful and knowledgeable entrepreneurs will lead to more effective responses to development such as globalization and reforms in agricultural policies. In answer to our first Interview question, what knowledge do you have about the basics of entrepreneurship and its interactive effect on the economic development of Ghana? We can say that the farmer entrepreneur acquire knowledge through training which results in the entrepreneur being a strategic planner, managing people well and knowing how to use technology. Such knowledge will assist these farmers differentiate their farms from others in the same sector. The second Interview question which is related to the acquisition of skills was well answered and resulted in the farmer entrepreneur being more skillful enabling him to be a goal getter, negotiator and a risk taker. The last questions were answered with results of positive behavior and attitude of the farmer making him proactive, tolerant and persevere.

The linkage for the economic development means farmer entrepreneur has knowledge, skills and positive attitude to enhance their entrepreneur behavior. The theoretical framework used entrepreneur competence theory linking competencies and competence to 'KSA' theory and some well entrepreneur models. There are also some discussions on some methodological issues relating to adopting GT as the research method. A description of the initial phase of data collection, coding and analysis process with discussions of some initial findings is done. The researchers need to note some few issues on this study. As a requirement by constant comparative method, after each session of interview, data analysis has to be done immediately. Also to obtain more data when necessary, follow-up interview may be needed to conclude the study. Finally developing trust with participants is very important to produce quality data and ensure trustworthiness of research findings. At the concluding stage of this study, the researchers are expected to provide findings that will add to the existing literature of the interactive effect of farmer entrepreneur and the economy of Ghana.

\subsection{Limitation and further Research}

The study as it has been carried out is not meant to be conclusive. The initial sample of 50 farmers which was used to come to a more stratified sub-sample could serve as a starting point for such a study. It would be interesting to study the above outlined study on a more quantitative basis that means quantitative and qualitative have their own advantages and disadvantages. For instance, in this study most of the issues discussed are based of qualitative which means the degree of reliability may not be so high and conclusive. Also some problems cannot be research; how much the entrepreneur behavior can change was not measured and calculated. For purposes of clarity and readability, limited editing of the texts was done. These processes 
can introduce the possibility of losing meaning and context of some of the data. However, because of the familiarity with the local language, issues associated with farmer entrepreneur, and the fact that all the interviews were recorded on audio tapes and notes taken, any discrepancies in translation were crossedchecked very well. This was done by listening to the tapes many times and cross-checking with the notes to ensure that the original meaning and integrity of the accounts were transcribed.

Another interesting area for additional research is the inclusion of agriculture clusters managed by a team, a phenomenon which would be seen more often in future due to the steady increase of agro based clusters. Also further research can be done into a more scientific measuring of the behavior of the farmer entrepreneur. Other research on farmer entrepreneur can be the performance of entrepreneur and upgrading. In the nearest future the above can be research.

\section{References}

1) Abdel-Fattah, M. A. (2015). Grounded theory and action research as pillars for interpretive information systems research: A comparative study. Egyptian Informatics Journal, 16(3), 309-327.

2) Acs, Z. J., Desai, S., \& Hessels, J. (2008). Entrepreneurship, economic development and institutions. Small business economics, 31(3), 219-234.

3) ADEYEMI, D. (2012). ENTREPRENEURSHIP AND SMALL BUSINESS A CASE OF A DEVELOPING COUNTRY.

4) Bank, W. B. W. (2014). State and trends of carbon pricing 2014: World Bank Publications.

5) Bingwen, Z. (2011). Middle Income Trap" and China's Path to Development: In Perspective of International Experiences and Lessons [J]. Chinese Journal of Population Science, 1, 001.

6) Bjerke, B., \& Hultman, C. (2004). Entrepreneurial marketing: The growth of small firms in the new economic era: Edward Elgar Publishing.

7) Breisinger, C., Diao, X., \& Thurlow, J. (2009). Modeling growth options and structural change to reach middle income country status: The case of Ghana. Economic Modelling, 26(2), 514-525.

8) Cantillon, R. (1755). Essai sur la nature du commerce en général (Vol. 29): chez Fletcher Gyles.

9) Charmaz, K. (2014). Constructing grounded theory: Sage.

10) Corbin, J., \& Strauss, A. (2008). Basics of qualitative research: Techniques and procedures for developing grounded theory.

11) Council, n. R. (2013). Education for life and work: Developing transferable knowledge and skills in the 21st century: National Academies Press.

12) Drucker, P. (2014). Innovation and entrepreneurship: Routledge.

13) Friend, M. P., \& Cook, L. (1992). Interactions: Collaboration skills for school professionals: Longman New York.

14) Glaser, B. G., \& Holton, J. (2004). Remodeling grounded theory. Paper presented at the Forum Qualitative Sozialforschung/Forum: Qualitative Social Research.

15) Gunawan, A. A. (2014). Preliminary study of classifying indonesian entrepreneurs. Procedia-Social and Behavioral Sciences, 115, 243-250.

16) Hafeez, K., Zhang, Y., \& Malak, N. (2002). Core competence for sustainable competitive advantage: A structured methodology for identifying core competence. IEEE transactions on engineering management, 49(1), 28-35.

17) Hamid, W. W., Saman, M. M., \& Saud, M. (2012). Exploring factors influencing the transfer of training using a grounded theory study: Issues and research agenda. Procedia-Social and Behavioral Sciences, 56, 662-672.

18) Hassan, T. M. R. T., Yaacob, M. R., \& Abdullatiff, N. K. (2014). Sustaining SMEs wood-based product manufacturing through best practices-The case of indigenous entrepreneurs in Kelantan. ProcediaSocial and Behavioral Sciences, 115, 221-234.

19) Hazlina Ahmad, N., Ramayah, T., Wilson, C., \& Kummerow, L. (2010). Is entrepreneurial competency and business success relationship contingent upon business environment? A study of Malaysian SMEs. International Journal of Entrepreneurial Behavior \& Research, 16(3), 182-203. 
20) Hughes, J., \& Jones, S. (2003). Reflections on the use of grounded theory in interpretive information systems research. ECIS 2003 Proceedings, 62.

21) Jamali, D. (2009). Constraints and opportunities facing women entrepreneurs in developing countries: A relational perspective. Gender in Management: An International Journal, 24(4), 232-251.

22) Kirby, D. A. (2004). Entrepreneurship education: can business schools meet the challenge? Education+ training, 46(8/9), 510-519.

23) Kivirist, L., \& Ivanko, J. (2008). ECOpreneuring: Putting Purpose and the Planet Before Profits: New Society Publishers.

24) Landstrom, H. (1999). The roots of entrepreneurship research. New England Journal of Entrepreneurship, 2(2), 9.

25) Lee, J.-S., \& Hsieh, C.-J. (2010). A research in relating entrepreneurship, marketing capability, innovative capability and sustained competitive advantage. Journal of Business \& Economics Research, 8(9), 109.

26) Li, X. (2009). Entrepreneurial competencies as an entrepreneurial distinctive: An examination of the competency approach in defining entrepreneurs.

27) Man, T. W., Lau, T., \& Chan, K. (2002). The competitiveness of small and medium enterprises: A conceptualization with focus on entrepreneurial competencies. Journal of business venturing, 17(2), 123-142.

28) McMullen, J. S., \& Shepherd, D. A. (2006). Entrepreneurial action and the role of uncertainty in the theory of the entrepreneur. Academy of Management review, 31(1), 132-152.

29) Naudé, W. (2010). Entrepreneurship, developing countries, and development economics: new approaches and insights. Small business economics, 34(1), 1-12.

30) Navale, A. B. (2013). Developing entrepreneur skills for corporate work. Research Directions, 1(4).

31) Niosi, J. (2002). National systems of innovations are "x-efficient"(and x-effective): Why some are slow learners. Research policy, 31(2), 291-302.

32) Parker, L. D., \& Roffey, B. H. (1997). Methodological themes: back to the drawing board: revisiting grounded theory and the everyday accountant's and manager's reality. Accounting, Auditing \& Accountability Journal, 10(2), 212-247.

33) Patton, M. Q. (2005). Qualitative research: Wiley Online Library.

34) Porter, M. E. (1990). The competitive advantage of nations: New York: Free Press.

35) Porter, M. E., \& Kramer, M. R. (2002). The competitive advantage of corporate philanthropy. Harvard business review, 80(12), 56-68.

36) Quaye, A. K., Hall, C. A., \& Luzadis, V. A. (2010). Agricultural land use efficiency and food crop production in Ghana. Environment, development and sustainability, 12(6), 967-983.

37) Raposo, M., \& Do Paço, A. (2011). Entrepreneurship education: Relationship between education and entrepreneurial activity. Psicothema, 23(3), 453-457.

38) Richomme-Huet, K., \& De Freyman, J. (2011). What sustainable entrepreneurship looks like: An exploratory study from a student perspective. Paper presented at the ICSB World Conference Proceedings.

39) Rihova, I., Buhalis, D., Moital, M., \& Gouthro, M. B. (2015). Conceptualising customer- to- customer value co- creation in tourism. International Journal of Tourism Research, 17(4), 356-363.

40) Rostow, W. W. (1960). TheStagesofEconomicGrowth. A non-communist manifesto. Cambridge/Mass.

41) Sahoo, M. P., Kalyani, M., \& Hathy, P. R. (2014). Socio-Psychological Correlations with Tribal Entrepreneurships in the SC \& ST Community Development of Mayurbhanj and Rayagada district of Orissa (India). International Journal of Application or Innovation in Engineering \& Management, 3(1), 193-203.

42) Sapir, A. (2003). An Agenda for a Growing Europe: Making the EU Economic System Deliver: Report of an Independent High-level Study Group Established on the Initiative of the President of the European Communities: European Commission. 
43) Sarwoko, E., Surachman, A., \& Hadiwidjojo, D. (2013). Entrepreneurial characteristics and competency as determinants of business performance in SMEs. IOSR Journal of Business and Management, 7(3), 31-38.

44) Saunders, M., Lewis, P., \& Thornhill, A. (2003). Selecting samples. Research methods for business students, 3.

45) Say, J. B. (1997). An Economist in Troubled Times: Writings: Tor/Forge.

46) Schumpeter, J. A. (1934). The theory of economic development: An inquiry into profits, capital, credit, interest, and the business cycle (Vol. 55): Transaction publishers.

47) Shane, S. (2009). Why encouraging more people to become entrepreneurs is bad public policy. Small business economics, 33(2), 141-149.

48) Small, J., Melewar, T., Yin Wong, H., \& Merrilees, B. (2007). Multiple roles for branding in international marketing. International Marketing Review, 24(4), 384-408.

49) Spencer, L. M., \& Spencer, P. S. M. (2008). Competence at Work models for superior performance: John Wiley \& Sons.

50) Swee, G. K. (2013). The practice of economic growth: Marshall Cavendish International Asia Pte Ltd.

51) Tan, J. (2010). Grounded theory in practice: issues and discussion for new qualitative researchers. Journal of Documentation, 66(1), 93-112.

52) Teece, D. J. (2007). Explicating dynamic capabilities: the nature and microfoundations of (sustainable) enterprise performance. Strategic management journal, 28(13), 1319-1350.

53) Toporek, R. L., Lewis, J. A., \& Crethar, H. C. (2009). Promoting systemic change through the ACA advocacy competencies. Journal of Counseling \& Development, 87(3), 260-268.

54) Unicef. (2014). WHO \& The World Bank. 2012. Levels and trends in child malnutrition: Joint child malnutrition estimates.

55) $<$ Value chain guava.pdf $>$.

56) Van Kleef, J., \& Roome, N. (2007). Developing capabilities and competence for sustainable business management as innovation: a research agenda. Journal of Cleaner Production, 15(1), 38-51.

57) Verheul, I., Wennekers, S., Audretsch, D., \& Thurik, R. (2002). An eclectic theory of entrepreneurship: policies, institutions and culture Entrepreneurship: Determinants and policy in a European-US comparison (pp. 11-81): Springer.

58) Walls, P., Parahoo, K., \& Fleming, P. (2010). The role and place of knowledge and literature in grounded theory: Paula Walls, Kader Parahoo and Paul Fleming discuss how novice researchers can justify the use of grounded theory while avoiding breaking any of its tenets. Nurse Researcher, 17(4), 8-17.

59) Walsham, G. (2006). Doing interpretive research. European journal of information systems, 15(3), 320-330.

60) WHO, U. (1990). UNFPA, \& The World Bank.(2012). Trends in maternal mortality, 2010.

61) Wu, B., \& Knott, A. M. (2006). Entrepreneurial risk and market entry. Management science, 52(9), 1315-1330.

62) Zereyesus, Y. A., Ross, K. L., Amanor-Boadu, V., \& Dalton, T. J. (2014). Baseline feed the future indicators for northern Ghana 2012. Kansas State University, Manhattan, KS, 33.

\section{Research grant}

Project Funds:[1] Self -organized cluster entrepreneurship behavior reform, evolution and promotion strategies study(No.16BGL028) ,China National Social Science Foundation; [2]Study on Bottleneck and Innovation of Post- industrial Intellectual capital development in Jiangsu Province (No.14JD009), Jiangsu Province Social Science Foundation Project.[3]Interactive effect between Self-Organized Innovation and Industrial cluster,Jiangsu Province Graduate Scientific Research Innovation Project. (KYCX17_1746) 